\title{
Törő Blanka': A kérdezés jelentősége a tanúvallomás során
}

Debreceni Jogi Műhely, 2010. évi (VII. évfolyam) 2. szám (2010. április) 60-70.

\section{Bevezetés}

A büntetőeljárás egyik jelentős mozzanata közé tartozik a tanúk kihallgatása. A tanúk által vázolt történésekből és jelenségekből körvonalazódnak az ügy körülményei. A kihallgatás során a tanú összefüggően előadja az általa átélt, érzékelt eseményeket. Ezt követően a kihallgatást végző személy kérdéseket intéz a tanúhoz, melyekkel kidomborodnak a fontosabb, az eljárás folyamán értékelhető, büntetőjogilag relevanciával bíró részletek.

A kérdésfeltevés joga hatalmat kölcsönöz a kihallgatást végző személynek. Ennek a hatalomnak a birtokában, a kérdező irányítja, felügyeli, és meghatározott irányba terelheti a tanú vallomását és az ügy kimenetelét. A kérdésekkel a kihallgatást végző személy képes befolyást gyakorolni a tanúra.

A szakirodalmakban való tájékozódásom, illetve az általam végzett, és tanulmányom végén ismertetett kísérlet is azt bizonyítja, hogy a szuggesztív kérdések manipulációs jellegük miatt képesek arra, hogy a tanú vallomását befolyásolják, a tanú emlékezetére, emlékképeire és érzelmeire kihassanak. A szuggesztív, más néven rávezető kérdések tulajdonképpen egy előre felajánlott választ hordoznak magukban. A tanú a kérdés hallatán valahol mélyen az elméjében úgy érzi, azt kell válaszolnia, amit a kérdés sugall, ez az érzete sokkalta erősebb annál, amit esetleg a memóriája diktálna. Így a válaszában a kihallgatást végző által szuggerált gondolatok fognak tükröződni, nem pedig az a valóság amit, a tanú érzékelt és memorizált.

\section{A tanú fogalma}

A tanú fogalmának meghatározása körül évek óta viták folynak. A szabályozás, ahogy máshol sem, itt sem teljesen egyértelmü és olykor nem következetes.

A problémák leginkább annak a meghatározása során merülnek fel leginkább, hogy mikor válik az adott személy tanúvá, mely időponttól válik esedékessé tanúvá minősítése. Az, hogy valaki látott vagy halott valamit, ezáltal valamilyen eseménynek szem- vagy fültanújává vált, nem jelenti azt, hogy az illető tanúnak minősül. Ugyanis nem biztos, hogy az a történés, amit a személy valamilyen módon érzékelt büntetőjogilag relevanciával bír.

Mégis ha általánosságban szeretnénk megfogalmazni a tanú fogalmát, akkor ahhoz, hogy valaki tanúvá válhasson, két feltétel együttes meglétének kell eleget tennie:

1. Az észlelés olyan jogilag releváns, történésekre, információkra, körülményekre vonatkozzon, amely a büntetőeljárás alapjául szolgálhatnak

2. Az adott személy valamely hatóság intézkedése következtében jogviszonyba kerüljön a büntetőeljárással és az ügyben tanúi minőségben szerepeljen. ${ }^{2}$

A Büntetőeljárásról szóló 1998. évi XIX. törvény (a továbbiakban Be.) szerint:

79. § (1) Tanúként az hallgatható ki, akinek bizonyítandó tényről tudomása lehet.

A bizonyítandó tények relevanciájáról pedig, a Be. 75 -ának (1) és (2) bekezdése rendelkezik: 75. § (1) A bizonyítás azokra a tényekre terjed ki, amelyek a büntető és a büntetőeljárási jogszabályok alkalmazásában jelentősek. A bizonyítás során a tényállás alapos és hiánytalan, a valóságnak megfelelő tisztázására kell törekedni, azonban, ha az ügyész nem indítványozza, 
a bíróság nem köteles a vádat alátámasztó bizonyítási eszközök beszerzésére, és megvizsgálására.

(2) A bizonyítás a büntetőeljárás járulékos kérdéseinek - különösen a polgári jogi igénynek elbírálásában jelentős tényekre is kiterjedhet.

\section{A tanú kihallgatásának menete, kiemelve a kérdezés stádiumát}

A hatályos jogi szabályozás több fázisban rendelkezik a tanú kihallgatásáról. Főszabályként a Be. 85-88. §-ban a kihallgatás általános szabályait rögzíti.

A nyomozás során történő kihallgatásról a Be. 181. $\S$, a nyomozási bíró által végzett tanúkihallgatásról a Be. 207. §, míg a tanúk tárgyalási kihallgatását a Be. 292-296. § részletezi. $^{3}$

$\mathrm{Az}$ előbb felsorolt fázisok mindegyikénél fontos szerephez jutnak az ott résztvevő, kihallgatást végző személyek, függetlenül attól, hogy ők a nyomozás vagy a tárgyalás során jelennek meg.

A bizonyítás kimenetele jelentősen függ ezen személyek viselkedésétől, megnyilvánulásától és a tanúkhoz való hozzáállásuktól.

Az egyik legfontosabb követelmény, hogy a kihallgatást végző személy megfelelően felkészüljön az üggyel kapcsolatosan.

Mikolay Sándor szavait idézve:

„A felkészülés során egyetlen feladat, hogy minél többet megtudjunk a kihallgatandó személyről és az ügyről.",

A felkészülés milyensége (tartalma, időtartama, módja) mindig az adott ügytől függ, de tény, hogy minél több információval rendelkezik a kihallgatást végző személy, annál hatékonyabban tudja feladatát ellátni, és annál biztosabbá válik a kihallgatás eredményessége.

Minden fázis elengedhetetlen eleme az exploráció, azaz a kiemelés, kifürkészés. ${ }^{5} \mathrm{Az}$ exploráció során a cél a tanúval való kapcsolatfelvétel. Ilyenkor a kihallgatást végzőnek el kell érnie, hogy a tanú megnyíljon számára, kész legyen arra, hogy minél pontosabban adja át az általa hordozott információkat.

Nem elenyésző esetben a tanú félelemmel telítődve, zavartan áll a kihallgatás elé. Feszült, szorong, és kiszolgáltatottnak látja helyzetét. ${ }^{6}$

Ezek az érzések mind megakadályozzák abban, hogy a vallomását pontosan és kimerítően megtegye és felidézze az emlékezetébe vésett képeket.

Ahhoz, hogy a kihallgatást végző személy feloldja a tanúban lévő kételyeket és bizalmatlanságot, megértést, együtt érzést és türelmet kell a tanúval szemben tanúsítani. Nem szabad a tanúhoz megalapozatlan elöítéletekkel állni. A tanú személyiségének elfogadásával az első lépést teszi meg a kihallgatást végző, annak érdekében, hogy a vallomástétel eredményre vezessen az ügy szempontjából.

A tanúvallomás összefüggő előadásának lehetőségét általános szabályként a Be. 88.-ának (1) bekezdése is biztosítja:

88. § (1) A kihallgatása során a tanú a hozzá intézett kérdésekre válaszol, de arra is módot kell neki adni, hogy a vallomását összefüggően előadja; ennek során - a tanú védelmére vonatkozó szabályok figyelembevételével - tisztázni kell azt is, hogy a tanú az általa elmondottakról miként szerzett tudomást. Ha a tanú vallomása eltér a korábbi vallomásától, ennek okát tisztázni kell. Az eljárás azonos szakaszában a tanú újabb kihallgatásánál a személyi adatokat - ha azok nem változtak - nem szükséges rögzíteni. 
A kihallgatást végzőnek fel kell kérnie a tanút arra, hogy összeszedetten, teljes egészében kimerítő előadásában jelenítse meg azokat a körülményeket, jelenségeket, tényeket, amelyeket az esemény során észlelt. ${ }^{7}$

A tanú kihallgatásának minősége attól függ, hogy éppen milyen szakaszban van az ügy.

A nyomozási szak kezdeti stádiumában gyakran ömlesztetté, követhetetlenné válik a kihallgatás. Ilyenkor ugyanis a fő cél a tanú birtokában lévő összes információ elnyerése, az ügy legapróbb részleteinek megszerzése. A kihallgatást végző személy ebben az esetben nem igyekszik célzott kérdéseket intézni a tanúhoz, inkább teret enged a tanú előadásának kibontakozásához. Türelmesen végighallgatja a tanú emlékképeinek szárnyalását, amely sokszor nem éppen összeszedett sorrendben történik.

Azonban a bizonyítás előre haladtával, egyre jobban kirajzolódnak a tanú által átélt események, és ezáltal egyre élesebbé válnak azok a részletek, amelyek az eljárás során és az ügy kapcsán is relevanciával bírnak.

Ez esetben a tanú gondolatait a lényeges vonásokra és fontosabb momentumokra kell terelnie a kihallgatást végzőnek. Rá kell vezetni a tanút arra, hogy kiemelje és megjelölje az ügy jelentősebb részeit. Sokszor erre figyelmeztetni kell, és gátat kell szabni mondanivalója tartalmának, hiszen a tanú nem érzékeli, mi számít az ügy szempontjából értékelhető és kellő bizonyító erejü jelenségnek. ${ }^{8}$

A kihallgatás előrehaladott szakaszában jelenik meg az általam vizsgált kérdezés stádiuma. A kihallgatást végzőnek a kérdezés során sok tényezőre kell figyelmet fordítania.

A kihallgatás ezen szakaszában ugyanis egy különleges viszony alakul ki a kihallgatást végző személy és a tanú között. A kihallgatást végző személy a vezető pozícióba, míg a tanú a vezetett helyzetébe kerül. A kérdezés tulajdonképpen egyfajta hatalom, illetve annak megnyilvánulási formája a kihallgatást végző kezében.

Ennek kapcsán Johannes Herwig- Lempp így fogalmazott:

„A kérdezés hatalmat kölcsönöz - és fordítva, akinek hatalma van, az kérdezhet.",9

A kérdezés során és ennek a hatalomnak a birtokában nyílik igazán lehetőség az információk tisztázására. Ezalatt törekedni kell az említett tények, adatok forrásának megismerésére.

A kérdezés szakaszában ugyanis nem kizárt, sőt akár a helyes kérdezéssel egyenesen biztosított az új információk megjelenése, felderítése. ${ }^{10}$

\section{Kérdéstípusok}

A kérdéstípusok meghatározása során különböző nézetekkel, felfogásokkal találkozhatunk. A magyar nyelvtan logikai hagyománya a kérdő mondatokat szemantikai (nyelvi jelentéstani) szerkezetük alapján 4 csoportba osztja: ${ }^{11}$

1. Eldöntendő kérdések

2. Választó kérdések

3. Kiegészítendő kérdések

4. Nyitott kérdések

Véleményem szerint azonban a büntetőeljárás alatt, és a kihallgatás során ennél jelentősen több típusú kérdés különböztethető meg egymástól. Ezen állításomat a szakirodalmakban, folyóiratokban olvasottak és az általuk képviselt álláspontok is alátámasztják. 
A kutatásom és vizsgálataim alapján bátorkodtam ezen nézetek, felfogások alapján egy saját forma rendszert felállítani, amely szerint, a kérdések típusai közt három nagy osztályt és ezen belül több alcsoportot különböztetek meg.

A három osztály:

1. Eldöntendő kérdések (zárt rendszerü kérdések)

2. Nyitott kérdések

3. Irányító kérdések

Az eldöntendő kérdés esetén elegendő a rövid válaszadás. A válaszoló fél, jelen esetben a tanú nem kap lehetőséget gondolatainak kifejtésére, csak száraz tények képében jelenítheti meg azokat. ${ }^{12}$

Az ilyen kérdések szemantikai szerkezete egyszerübb, tulajdonképpen az ilyen kérdés feltevésekor a kérdező megkönnyíti a választ adó dolgát, ugyanis a lehetséges válaszlehetőségek csekélyek, nem okozhat problémát a válasz megfogalmazása.

\section{Az eldöntendő kérdéseken belül három alcsoport különböztethető meg:}

a) Igen-nem kérdések

b) Alternatív (választó) kérdések

c) Adatokra vonatkozó kérdések

Az igen-nem kérdéstípus feltevésekor a válaszlehetőség száma kettőre korlátozódik, igenre vagy nemre. Ilyen kérdés esetén nem igényelnek magyarázatot a válaszok. Az, hogy a választ mégis valamilyen közléssel kiegészíti a válaszoló, az csakis tőle függ. ${ }^{13}$

Pl.: Van testvére?

Az alternatív kérdések már magukban hordozzák az esetleges válaszhalmazt, azonban a válaszok köre még itt is erősen zárt. A lehetséges válaszok a kérdezéssel a válaszoló elé vannak tárva.

A kérdéssel a választ adó előre meghatározott alternatívát kap. ${ }^{14}$

Pl.: Kék vagy piros színű volt a sértett szoknyája?

Az adatokra vonatkozó kérdések szilárd tényekre vonatkoznak A zárt rendszerü kérdések csoportjába tartoznak, mert a választás lehetősége igen korlátozott. Arra, hogy „Milyen idős a bátyja?" nem lehet azt válaszolni, hogy 10, 11 és 12 éves. Ezek a kérdések könnyen felismerhetőek a bennük lévő kérdőszavakból. Például a „Ki?”-re egy nevet, a „Milyen hosszú?”-ra egy időtartamot vagy távolságot, a „Hány?”-ra pedig egy számot várunk el a választ adótól.

P1.: Hány ember volt a szobában?

Milyen hosszú ideig várakozott?

Nyitott kérdések esetén a tanúnak esélye van komplex mondatokban és összefüggö leírásban kinyilvánítania válaszait. A nyitott kérdések a válasz megformálásának nagy teret engednek. Nem tartalmaznak előre meghúzott határokat. A tanú szabad akaratán múlik, milyen részletesen válaszol a feltett kérdésre. A nyitott kérdéseket úgy kell feltenni, hogy a válaszoló jelen esetben a tanú érezze, hogy nem adhat rövid választ. A nyitott kérdések által tudhatja meg a legtöbb információt a kihallgatást végző, kérdező személy. A tanú ugyanis észrevétlenül újabb tényeket és körülményeket közölhet, hiszen a nyitott kérdések esetén nincsen „felkészülési idő”, a tanúnak nem nyílik lehetősége, hogy minden egyes mondatát átgondolja a kérdéssel kapcsolatban.

A nyitott kérdéseken belül öt alcsoport különböztethető meg: 

a) Leírásra vonatkozó kérdések
b) Okra irányuló kérdések
c) Szándékra irányuló kérdések
d) Következtetésre irányuló kérdések
e) Érdeklődést kifejező kérdések

A leírásra vonatkozó kérdések a tanúnak lehetóséget adnak arra, hogy élményeit, megfigyeléseit, érzéseit közölje és körülírja. Ezen kérdéseknél az eldöntendő kérdések válaszolása alatt „elfojtott, elzárt” gondolatait közölheti. Lehetősége nyílik arra, hogy egy adott személyt, jelenséget, történést, érzést, észlelést részletesen leírjon és kifejtsen. ${ }^{16}$

Pl.: Hogyan tölti mindennapjait?

Milyen a viszonya az édesanyjával?

Az okra irányuló kérdéseknél a tanúnak a válaszában bizonyos viselkedésének, érzelmeinek, felfogásának magyarázatát kell megfogalmaznia. Ezek a kérdések döntően arra késztetik a tanút, hogy a múltba nézve keresse meg a cselekedeteinek, érzéseinek okait.

Ezek a kérdések könnyen felismerhetőek, hiszen szinte kivétel nélkül tartalmazzák a „miért” kérdőszót. ${ }^{17}$

P1.: Miért nem jó a kapcsolata a testvérével?

A szándékra irányuló kérdések könnyen összetéveszthetők az okra irányuló kérdésekkel. Azonban ezeknél a kérdéseknél a kihallgatást végző nem okokat keres, és nem múltbeli indokokat kíván feltárni a tanú elbeszélése alapján, hanem a jövőre vonatkoztatva, a tanú viselkedésének szándékára igyekszik rávilágítani. Arra akar rájönni a kérdező, hogy milyen céllal cselekedett a tanú, mit akart magatartásával elérni a jövőben. ${ }^{18}$

P1.: Mi volt a célja ezzel a tettével?

Mit akart azzal elérni, hogy visszautasította a segítségét?

A következtetésre irányuló kérdés feltevésekor a kérdező, azaz a kihallgatást végző személy a tanúnak az üggyel kapcsolatos következtetéseit akarja megismerni. Tulajdonképpen a tanúnak, az eseményekkel kapcsolatban kialakított véleményét akarja kideríteni az ilyen kérdések által. ${ }^{19}$

Pl.: Az ön véleménye szerint miért tette ezt az elkövető?

Az érdeklődést kifejező kérdések esetén a kihallgatást végző nem elégszik meg a tanú által adott válasszal. A tanútól egy pontosabb, cizelláltabb választ vár.

Ezen kérdéssel az előzőekben feltett kérdésére adott válaszokat akarja konkretizálni, részleteit feltárni a kihallgatást végző személy.

Az ilyen kérdésekkel a kérdező személy érezteti a tanúval, milyen nagy jelentőséggel bír az ő személye és vallomása az eljárás folyamán. ${ }^{20}$

Pl.:

- Milyen volt a kapcsolata Ilonával?

- Jól megértettük egymást.

- Mit ért azalatt, hogy jól megértették egymást?

Az irányító kérdés sokban különbözik az előző két osztálytól. Míg a nyitott, illetve az eldöntendő kérdések feltevésével a kihallgatást végző személy az üggyel kapcsolatos körülményeket, információkat és a tanú személyiségét, érzelmi-lelki kvalifikáltságát igyekszik feltárni. Ezen kérdések során a tanú és a kihallgatást végző személy közt egyfajta partneri viszony alakul ki. Természetesen, ahogy már az előzőekben említettem, ettől 
függetlenül a kihallgatást végző személy még a vezető pozíciójában van, csak a nyitott és az eldöntendő kérdéseknél sokkal kevésbé érzékelhető, és kimutatható ez a viszony, mert ezeknél a kérdéseknél a tanú, azaz a válaszoló sokkal szabadabban „mozoghat” saját gondolatainak világában és emlékezetében. Tulajdonképpen az eldöntendő és a nyitott kérdéseknél a kihallgatást végző vezető szerepe háttérbe szorul és egyfajta „hallgatóként” viselkedik, míg ezen kérdéseknél a tanú az „előadó” képében jelenik meg.

Az irányító kérdéseknél a helyzet pontosan fordítva írható le. A tanú és a kihallgatást végző személy közt egy alá-fölérendeltségi viszony jelenik meg. Ez a hierarchikus viszony már a külvilágban is érzékelhető lesz, természetesen ez nem azt jelenti, hogy a kérdező támadó, agresszív magatartást tanúsít és megfélemlíti a válaszolót. Inkább a tanúnak egyfajta korlátozását jelenti. Az irányító kérdések esetén a kérdező kicsit kétkedve és bizalmatlanul áll a tanúhoz. Megpróbálja kifürkészni a valótlan állításokat, a hamis tanúvallomás jelenlétét, felszínre hozni a tanú által esetleg eddig tudatosan titkolt részleteket.

Az irányító kérdéseken belül 5 csoport különíthető el:
a) Terelő kérdés
b) Tesztkérdés
c) Retorikai kérdés
d) Ellenőrző kérdés
e) Fogós kérdés

A terelő kérdés által a kérdező személy a kihallgatás menetét az általa kitüzött, meghatározott irányba terelheti. Ha a tanú úgymond eltér a tárgytól és gondolatai jelentéktelen részletekben kalandoznak el, a kihallgatást végző egy jól irányzott, terelő kérdéssel a „helyes mederbe” terelheti vissza a tanú vallomását. Ha a tanú esetlegesen a kihallgatás során bizonyos kérdésekre, feltevésekre vagy körülményekre hevesen és érzékenyen reagál, felzaklatja magát, erre felfigyelve a kérdező a terelő kérdéssel könnyen „nyugodtabb vizek felé” irányíthatja a tanút. ${ }^{21}$

Pl.: Térjünk csak vissza arra, amikor a férje belépett az ajtón, mit is látott akkor?

A tesztkérdés egyfajta kontrollkérdés. A vallomás alaposságát, a tanú által megemlített tények valódiságát, a manipulálhatóság mértékét igyekszik felmérni. Az ilyen kérdések alkalmasak arra is, hogy a kérdező megállapítsa, milyen képességekkel rendelkezik a tanú. Milyen helyesen és pontosan képes megítélni egy adott dolog sebességét, távolságát, magasságát, vagy egy cselekmény időtartamát. Ha egy ilyen kérdésre a tanú feltűnően helytelenül vagy éppen hamisan válaszol, akkor az a vallomásának eddig letisztázott elemeit is megingathatja.

Pl.:

- Milyen közel állt a bankrablóhoz?

- Körülbelül 15 méterre.

- De hát onnan honnan láthatta azt, amit az előzőekben külön hangsúlyozott, hogy a rabló a bal felkarján egy „1950. Berlin” feliratú tetoválást viselt?

A retorikai kérdés során a kérdés funkciója csorbul, a kérdésből közlés lesz. A közlésben kifejezésre jut a kérdező véleménye, felháborodása, sőt néha a kérdésben egy választ nem igénylő felszólítás, megbotránkozás rejlik.

Ez a kérdés alkalmas arra, hogy a tanúban szégyenérzetet keltsen, újra átgondolja kijelentését vagy eltérítse arról az útról, melynek végére a kihallgatást végző egy hamis tanúvallomással találná szembe magát. ${ }^{23}$ 
P1.: És ekkor úgy gondolta, hogy az a legjobb megoldás, ha gyáva ember módjára a szekrénybe bújva nézi végig az eseményeket? Nincs lelkiismeret furdalása????

Az ellenőrző kérdések nagyban segítik a vallomás valódiságának, hitelességének, összefüggőségének értékelését. Az ellenőrző kérdésre adott válaszok megerősíthetik a kihallgatást végző alátámasztásait, következtetéseit, olykor azonban a válaszok meglepetést okoznak, és új információkra derül fény. ${ }^{24}$

P1.: Tehát akkor az Ön által elmondottak alapján a sértett egy vasvillával védekezett?

A fogós kérdéssel mérhető fel, hogy a tanú mennyire mond igazat. A hamisan tanúzó a fogós kérdésekbe hamar belebotlik és felfedi magát. Az ilyen típusú kérdés bújtatottan van jelen, a tanú nem is érzi, hogy a kérdező az ő leleplezésével próbálkozik. A kérdés felismerhetetlensége abban rejlik, hogy általában a kihallgatást végző igyekszik látszólag jelentéktelen dolgok irányába érdeklődni, és ezáltal a tanú biztonságban érzi magát, és szó szerint, véletlenül „kikotyogja” az idáig féltve őrzött titkokat. ${ }^{25}$

\section{Szuggesztív kérdések}

A szuggesztív kérdéssel kapcsolatos nézetek nagyon eltérőek lehetnek. Igazán az áltálam megjelölt három csoport egyikébe sem sorolhatóak be kétségek nélkül, de valahogy mégis mindhárom csoportban jelen lehetnek. A szuggesztív kérdéseket nem lehet taxatíve felsorolni, azok manipulációs jellegét egyszerüen érezni kell.

Igaz, hogy az ilyen kérdés hordoz magában bizonyos ismertető jegyeket, (Ugye? ; Nemde? ; Ez nem úgy van, hogy...? ; Nem lehet, hogy inkább...?) azonban ezeket a kérdéseket mégis az adott ügy viszonylatában, illetve a tárgyalási szituációban kell vizsgálni.

A szuggesztív kérdéssel kapcsolatos felfogások és a kérdéshez való viszonyulás elég bonyolult.

Az egyértelműen kimondható, hogy a rávezető jellegü kérdéseket a Be. kivételt nem ismerő módon tiltja. Ezt a tilalmat a 293. § (3) bekezdése hordozza magában, illetve a tanú kihallgatására a 293. § (2) bekezdése írja elő ugyanezen szabályokat, mely szerint, ha a kérdés alkalmas a vádlott befolyásolására, illetve magában foglalja a választ, ha a kérdés nem az ügyre tartozik, vagy arra illetéktelen személy tette fel, ha a kérdés a tárgyalás tekintélyét sérti, vagy ha ismételten ugyanarra a tényre irányul, a tanács elnöke a kérdésre a feleletet megtiltja.

Azonban a törvényben megfogalmazottak ellenére is két oldalról kell megközelíteni a szuggesztív kérdés létjogosultságát.

Az egyik oldalról az ilyen típusú kérdések a kihallgatás menetét előreviszik. ${ }^{26}$

Meggyorsítják azzal, hogy kimondatják a tanúval azt, amelyre a mondanivalójában folyamatosan utalt, de nem volt rá egyértelmü állítás. A szuggesztív kérdések is képesek arra, hogy új tényeket hozzanak felszínre. A szuggesztív kérdés akkor helyes, vagy nem helyes, de legalább hasznos, amikor a kihallgatást végző személy egyszerüen tudja, hogy a tanú hazudik vagy megpróbálja félrevezetni az ügyet és az éppen eljáró hatóságot.

A probléma csak az, honnan tudhatja pontosan a kérdező, hogy a tanú nem mond igazat. Mert ha a kihallgatást végző pontosan és kétséget kizáróan ismeri az ügy valós körülményeit, és e kapcsán tudja, hogy a tanú hamisan vall, akkor a kérdezés funkcióját veszti.

A kihallgatás legfőbb célja pontosan az, hogy az üggyel kapcsolatos minden körülményt felvezessünk, és ezek által segítsük alátámasztani az ügyben meghozott ítéletet. Fontos szabály, hogy a be nem bizonyított dolgokat nem szabad bebizonyítottnak tekinteni, mert akkor az egész eljárás és nem csak a kihallgatás veszítené el értelmét. ${ }^{27}$ 
Az előbb kifejtett érvek miatt nehezebben bizonyítható a szuggesztív kérdésfeltevés pozitív oldala, illetve nem elenyésző tény az sem, hogy Be. rendelkezése is a negatív oldalt erősíti.

A Be. szabályai helytállóak e téren. A befolyás ugyanis a tanú emlékezetére és emlékképeinek felidézésére károsan hat. ${ }^{28}$

A szuggesztív kérdés hatására a tanú az általa észlelt eseményeket, jelenségeket képtelen lesz a valóságnak megfelelően visszaadni. A kihallgatást végző a tanú szájába adott válaszokkal saját magát, és a tanút is félrevezetheti. A vallomás manipulálásával a kérdező a kihallgatás eredményességét, az ügy végkimenetelét, és nem utolsó sorban az ítélet helyességét és igazságosságát is veszélyezteti. ${ }^{29}$

Természetesen nem lehet ellenezni az olyan rávezető jellegü kérdések feltevését, amely a tanú vallomásában már elhangzottakra vonatkozik. ${ }^{30}$

\section{Kísérlet}

A szuggesztív kérdések befolyásoló erejét az általam végzett kísérlet is bizonyítja. 25 fös egyetemista csoportnak egy képet mutattam, amelyet körülbelül 10-15 másodpercig nézhettek. Felhívtam a figyelmüket arra, hogy próbálják meg a kép részleteit memorizálni, mert az idő leteltével kérdéseket fogok nekik feltenni, amelyre az emlékezetük alapján kell válaszolni. A képpel kapcsolatban 12 kérdést tettem fel a hallgatóknak, melyek között körülbelül hasonló arányban oszlott meg a szuggesztív és a befolyástól mentes kérdések száma.

Az általam feltett kérdések a következők:

1. Hány személy volt a szobában?

2. Volt a szobának ablaka?

3. Volt óra a szobában?

4. Láttad-e a vázát a szobában?

5. Volt-e benne virág?

6. Barna vagy fekete volt a nagypapa pulóvere?

7. Láttad-e a kislány játék mackóját?

8. Ugye voltak könyvek a polcon?

9. A fiú felsője zöld volt?

10. Pipázott-e a nagypapa?

11. Hányan ültek a képen?

12. Bal vagy jobb oldalon ült a nagypapa?

Az első kérdés az eldöntendő kérdések osztályába tartozik, ezen belül, az adatokra vonatkozó kérdések csoportjába. A szobában három személy volt, erre a kérdésre mind a 25 hallgató helyes választ adott. Ennek a kérdésnek nem volt befolyásoló jellege.

A második kérdés szintén az eldöntendö kérdések osztályába sorolható, ezen belül az igennem kérdések csoportjába. Ez a kérdés nem tartalmaz igazán intenzív befolyást, azonban azzal, hogy a kérdés grammatikailag kijelentésnek számít, kissé ezáltal szuggesztíven hangzik és egy bizonytalan tanú esetén képes manipulálni a memóriát. Erre a kérdésre 25 hallgatóból 20 helyesen válaszolt, mely szerint a szobában nem volt ablak. 5 személynél azonban sikerült befolyásolni az emlékezetet.

A harmadik kérdés, ahogyan az elöbbi is az eldöntendő kérdések osztályába sorolható, ezen belül az igen-nem kérdések csoportjába. Erre a kérdésre minden hallgató helyesen válaszolt mely szerint volt óra a szobában. Az óra egy ingaóra volt, mely nem annyira szokványos, 
ezáltal a kép egyik különlegesebb elemét képezte, így biztosítva, hogy a hallgatók kivétel nélkül emlékeztek rá.

A negyedik kérdés szuggesztív jellege sokkal erősebb, mint az előzőeké. Ez a kérdés is eldöntendő kérdés, a válasz lehetőség igenre vagy nemre korlátozódik. A szobában nem volt váza, mégis a 25 hallgató közül 19 látta a vázát. Ez a jelenség azzal magyarázható, hogy a kérdés nem arra vonatkozott, hogy a szobában található- e váza, hanem arra, hogy ők látták-e. Ezzel a kérdéssel mintha kijelentettem volna, hogy a váza a szobában volt, csak az iránt érdeklődtem, hogy ők észre vették-e. A helytelenül válaszoló 19 hallgató valószínüleg úgy gondolta a befolyás hatására, hogy az a helyes, ha azt válaszolja, hogy látta a vázát, még ha nem is emlékszik rá.

Az ötödik kérdés mutatja leginkább, milyen erővel bír a manipuláció az emlékezetre. A kérdés ismét egy eldöntendő kérdés volt, melyre igennel vagy nemmel lehetett válaszolni. Tehát 25 személyböl 19 látta a vázát, a 19-ből 11 ember a virágot is látott benne. A manipuláció által a 11 hallgató képes volt arra, hogy a nem létező vázában a virágot is lássa. Ez a kérdés duplán szuggesztív jellegü, mert úgy gondolhatták, minek tenném fel a kérdést, ha a vázában nem lenne virág. A válaszadás során, pedig az életük során tapasztalt tény is megerősíthette öket a virág voltáról, hiszen egy váza virág nélkül nehezen képzelhető el, mert akkor funkcióját vesztené.

A hatodik kérdés az eldöntendö kérdések osztályán belül az alternatív kérdések csoportjába sorolható. 25 hallgatóból 21 mondta, hogy a nagypapa pulóvere barna volt. 1 hallgató feketére emlékezett. 3 hallgató egyik színt sem vélte helyesnek. Ez a 3 hallgató volt képes arra, hogy elvonatkoztasson a befolyástól, és az emlékezetükre hagyatkozva jól döntsenek a kérdésben. A többi hallgatónál sikerült ezzel a szuggesztív kérdéssel kitörölni az emlékezetükből a kék színt.

A hetedik kérdés szintén az eldöntendő kérdések osztályán belül az igen-nem kérdések csoportjába tartozott. 25 személyből 15 látta a játék mackót, 4 nem látta és 6 hallgató képes volt felidézni azt, hogy a kislány kezében valójában egy játék nyuszi volt. Ezzel a kérdéssel szintén az eddigi tapasztalataikra, gyerekkori emlékeikre hagyatkozva próbáltam a hallgatók memóriáját befolyásolni. Mivel a gyermekek alaptevékenysége a játék, így senki sem tudna elképzelni egy kislányt játék nélkül. A játék mackó mivel a köztudatban sokkal klasszikusabb, többször előforduló játék, mint a nyuszi, ezért tizenöten a kérdésem hatására a mackóra emlékeztek.

A nyolcadik kérdés is erősen szuggesztív, szintén eldöntendő, igen-nem válaszlehetőséggel. Az „ugye” kérdőszó erősen manipulatív jelleggel bírt 25 hallgató közül 16-nál. A szobában nem volt polc, de az ,ugye” hatására még a könyveket is odaképzelték és megjelenítették a emlékezetükben a hallgatók.

A kilencedik kérdés is egy eldöntendő kérdés, a válasz lehetőség igenre vagy nemre szükül. Ez a kérdés nem bírt befolyásoló erővel így 25 hallgató közül mindenki jól válaszolt, vagy a kék vagy a zöld színt vélte helyesnek. Ez abból adódhatott, hogy a póló színe nem volt egyértelmü, így mind a két választ helyesnek ítéltem meg.

A tizedik kérdés ismét egy eldöntendő kérdés, melyre igennel vagy nemmel lehetett válaszolni. Szintén erős manipulációs jelleggel bír. 25 személyből 12 igennel, 13 hallgató nemmel válaszolt. A kép egy színes, megszokott, biztonságot sugárzó családi kapcsolatot ábrázol a nagypapa és unokái között. A kislány nevetgél, játszik a kisfiú a nagypapával farkas 
szemet néz. Az ősz nagypapa egy görbe botot tart a kezében. A kép hangulata, a nagyapó jelenléte a helytelenül válaszoló hallgatóknál valószínüsíthetően arra az asszociációra vezetett, hogy a nagypapát, mint egy igazi nagy öreget, nem lehetne pipa nélkül elképzelni.

A befolyásomat a bot is segíthette, mivel lehet, hogy a hallgatók emlékeztek valamilyen tárgyra a nagypapa körül, a ,pipa” szó hallatára bot képét töröltem az emlékezetükből.

A tizenegyedik kérdés egy eldöntendő kérdés, ezen osztályon belül az adatokra vonatkozó kérdések csoportjába tartozik. A kérdés nem tartalmazott semmilyen befolyást. A szobában ketten ültek, a nagypapa és a kisfiú. Erre a kérdésre mind a 25 hallgató jól válaszolt.

A tizenkettedik kérdés az eldöntendő kérdések osztályán belül az alternatív kérdések csoportjába sorolható. A kérdés szuggesztió mentes volt. A 25 hallgató közül mindannyian jól emlékeztek arra, hogy a nagypapa a szoba bal oldalán ült.

\section{Összefoglalás}

Természetesen a tanúk kihallgatása során többféle kérdéstípussal találkozhatunk, amit a kísérletemnél nem volt alkalmam bemutatni. Mégis ilyen szük körben is alkalmas volt arra a kutatásom, hogy a szuggesztív kérdések befolyásoló jellege nem csak egy feltevés, hanem bizonyított tény legyen. Függetlenül attól, hogy sok szakirodalom foglalkozik a szuggesztív kérdések problémájával, illetve a Be. is tesz lépéseket a szabályozás ügyében, mégis véleményem szerint nem fektetnek kellö hangsúlyt a kihallgatás ezen elemére. A büntető eljárásjog, csak úgy, mint a jogágak többsége nem csak száraz tényekböl, bonyolult rendelkezésböl áll. A büntetőeljárás központjában az ember áll. Az eljárás során legfőbb cél az kellene legyen, hogy minden lehetséges és törvényes módon információt kapjunk az ügyről. Minden adatnak, emléknek, körülménynek óriási jelentősége van. A befolyás hatására adott helytelen válaszok képesek arra, hogy megmásítsák a múltban történt eseményeket, ezáltal egy új tényállás körvonalait vázolják fel. Véleményem szerint azonban nem engedhető meg, hogy az eljárás során az elkövető sorsa ilyen válaszoktól függjön.

\section{Felhasznált irodalom}

1. Elek Balázs: A vallomás befolyásolása a büntetőeljárásban. Tóth Könyvkereskedés és Kiadó Kft., 2008, Debrecen

2. Jacsó István: A vallomásokat befolyásoló tényezők. Magyar Jog, 1975. 8. szám, 460464. o.

3. Johannes Herwig- Lempp: A helyes kérdezés módja. Pszichoterápia XI. évfolyam, 2002. december, 621-631. o.

4. Mikolay Sándor: Kommunikációs technikák a kihallgatáson. Belügyi Szemle, 1995. XXIII. évfolyam 7-8. szám

5. Molnár József: A kriminalisztika tudománya V.- A tanú és a terhelt kihallgatásáról. In.: Irk F. (szerk.): Kriminológiai és Kriminalisztikai Tanulmányok XXXVI., Közzéteszi: Országos Kriminológiai és Kriminalisztikai Intézet, Budapest 1999, 199245. o.

6. Seres András: A bírósági tanúkihallgatás taktikájáról. Jogtudományi Közlöny, 1968. 1. szám

7. Tanulmányok a mai magyar nyelv szövegtana köréből. Szerkesztők: Rácz Endre, Szathmári István, Tankönyvkiadó, Budapest, 1983

8. Varga Zoltán: A tanú a büntetőeljárásban. Complex Kiadó, Budapest, 2009 
${ }^{1}$ Joghallgató, Debreceni Egyetem Állam- és Jogtudományi Kar, Konzulens: Elek Balázs, egyetemi adjunktus

${ }^{2}$ Varga Zoltán: A tanú a büntetőeljárásban. Complex Kiadó, Budapest, 2009, 15. oldal

${ }^{3}$ Varga Z. (2009): im. 42. oldal

${ }^{4}$ Mikolay Sándor: Kommunikációs technikák a kihallgatáson. Belügyi Szemle, 1995. XXIII. évfolyam 7-8. szám 54. oldal

${ }_{6}^{5}$ Mikolay Sándor (1995): im. 54.oldal

${ }^{6}$ Seres András: A bírósági tanúkihallgatás taktikájáról. Jogtudományi Közlöny, 1968. 1. szám 40. oldal

${ }^{7}$ Molnár József: A kriminalisztika tudománya V.- A tanú és a terhelt kihallgatásáról. In.: Irk F. (szerk.):

Kriminológiai és Kriminalisztikai Tanulmányok XXXVI., Közzéteszi: Országos Kriminológiai és

Kriminalisztikai Intézet, Budapest 1999. 221. oldal

${ }^{8}$ Varga Zoltán (2009): im. 42. oldal

${ }^{9}$ Johannes Herwig- Lempp: A helyes kérdezés módja. Pszichoterápia XI. évfolyam, 2002, 398. oldal

${ }^{10}$ Molnár József (1999): im. 224. oldal

${ }^{11}$ Tanulmányok a mai magyar nyelv szövegtana köréböl. Szerkesztők: Rácz Endre, Szathmári István Tankönyvkiadó, Budapest, 1983, 229. oldal

${ }^{12}$ Tanulmányok a mai magyar nyelv szövegtana köréböl (1983): im. 209. oldal

${ }^{13}$ Johannes Herwig- Lempp (2002): im. 399. oldal

${ }^{14}$ Johannes Herwig- Lempp (2002): im. 399-400. oldal Tanulmányok a mai magyar nyelv szövegtana köréböl (1983): im. 213. oldal

${ }^{15}$ Johannes Herwig- Lempp (2002): im. 400. oldal

${ }^{16}$ Johannes Herwig-Lempp (2002): im. 400. oldal Elek Balázs: A vallomás befolyásolása a büntetőeljárásban. TKK., Debrecen, 2008, 148-149. oldal.

${ }^{17}$ Johannes Herwig- Lempp (2002): im. 399. oldal

${ }^{18}$ Johannes Herwig- Lempp (2002): im. 401. oldal

${ }^{19}$ Elek Balázs: im. 156. oldal.

${ }^{20}$ Johannes Herwig-Lempp (2002): im. 401. oldal

${ }^{21}$ Elek Balázs: im. 153. oldal.

${ }^{22}$ Elek Balázs: im. 153. oldal.

${ }^{23}$ Elek Balázs: im. 153. oldal.

${ }^{24}$ Elek Balázs: im. 155. oldal.

${ }^{25}$ Elek Balázs: im. 153. oldal.

${ }^{26}$ Molnár József (1999): im. 225. oldal

${ }^{27}$ Elek Balázs: im. 154. oldal

${ }^{28}$ Jacsó István: A vallomásokat befolyásoló tényezők. Magyar Jog, 1975. 8. szám, 462. oldal

${ }^{29}$ Molnár József (1999) im. 225. oldal

${ }^{30}$ Seres András (1968): im. 44. oldal 